УДК $364.3: 28$

DOI:

Галина Кузан, кандидат філологічних наук, доцент, доцент кафедри іноземних мов Національного університету “Львівська політехніка" Ніна Гордієнко, кандидат педагогічних наук, доиент кафедри соціальної педагогіки та корекційної освіти Дрогобицького державного педагогічного університету імені Івана Франка

\title{
ПРЕВЕНЦІЯ ДОМАШНЬОГО НАСИЛЬСТВА В УКРАЇНІ: ПРОБЛЕМИ ТА ПЕРСПЕКТИВИ
}

У пропонованій статті розглянуто однуз найактуальніших соціальних проблем та найбільш поширених форм порушення прав людини не тільки в Україні, але й у світі-домашнє насильство. На підставі проведеного емпіричного дослідження громадської думки стосовно різних аспектів домашнього насильства (його видів, причин та наслідків, поведінки людини у ситуачії домашнього насильства, поінформованості стосовно інституцій, до яких слід звертатися у таких випадках, бачення респондентами иляхів його превенцї та подолання тощо) зроблена спроба, з одного боку, окреслити причини, щзо гальмують проиес запобігання й протидї домашньому насильству, а з іншого - перспективи иієї ланки соціальної роботи в сучасних умовах України.

Ключові слова: домашнє насильство; причини і наслідки домашнього насильства; поведінкові практики людини, яка стала жертвою насильства; інновації у сфері попередження та подолання домашнього насильства.

Jim. 11.

Halyna Kuzan, Ph.D.(Philology), Associate Professor of the Foreign Languages Department National University "Lviv Polytechnic" Nina Hordiyenko, Ph.D.(Pedagogy), Associate Professor of the Social Pedagogy and Remedial Education Department Drohobych Ivan Franko State Pedagogical University

\section{PREVENTION OF DOMESTIC VIOLENCE IN UKRAINE: ISSUES AND PERSPECTIVES}

The following article covers one of the most up-to-date social issue and most wide spreading form of violation of human rights not only in Ukraine but in the whole world - domestic violence. Based on carried out empiric research concerning various aspects of domestic violence (its types, reasons and consequences, human behavior in the situation of domestic violence, information about institutions, which can be contacted to, respondents' realizing of ways of its prevention and overcoming, etc.) the attempt is made, on the one hand, to discover the reasons, that had a crucial impact on prevention and overcoming of domestic violence and on the other hand perspectives of the following link of social work under the current circumstances of Ukraine.

Survey, which was based on two groups of respondents' replies - young people among children-orphans and older generation (age 40-65) was proved that the most essential issues delaying process of overcoming domestic violence the first place take mental peculiarities of the perception of the phenomenon, efforts of the older generation not to reveal of secrets of the family (especially among older generation), misunderstanding of committing violent acts, disbelieve in possibility to get support and what is the most essential is lack of information given to the population relating the specific sphere, especially concerning innovations.

The conclusion is made, that organization of large-scale educational work in different issues of domestic violence, starting with its types, reasons of emerging and consequences, behavioral practice of a person, that became victim of violence, and spheres where the help could be possible to get, it is one of the actual way for breaking vicious circle of domestic violence that can be aimed at the whole population of Ukraine.

Keywords: domestic violence; reasons and consequences of domestic violence; behavioral practice of a person; that becomes a victim of violence; innovations in the sphere of prevention and overcoming violence.

П остановка проблеми. Домашнє насильство в умовах сьогодення виступає однією 3 найактуальніших соціальних проблем та найбільш поширених форм порушення прав людини як в Україні, так і у світі. За даними, оприлюдненими Управлінням ООН з наркотиків і злочинності, в країнах євросоюзу смертність від домашнього насильства серед жінок у віці 15-44 р. становить $19 \%$; у США жертвами домашнього насильства стають $40 \%$ жінок, а у Японії цей показник становить $59 \%$ [4]. В Україні показники злочинів, скоєних внаслідок домашнього насильства, також невтішні: "майже 40 \% від загального показника 


\section{ПРЕВЕНЦІЯ ДОМАШНЬОГОНАСИЛЬСТВА В УКРАЇНІ:ПРОБЛЕМИ ТАПЕРСПЕКТИВИ}

усіх зареєстрованих убивств становлять злочини, викликані насильством у колі сім'ї; 69 \% випадків сексуального насильства над дітьми в Україні здійснюється в домашніх умовах, у неблагополучних сім'ях" [4], майже 70 \% жінок піддаються різним формам знущань і принижень, понад 3 мільйони дітей в Україні стають свідками насильства у своїх сім'ях або їх жертвами [2].

Загалом, за повідомленнями Мінсоцполітики, в Україні спостерігається тенденція до зростання випадків домашнього насильства, різні види якого проявляються у кожній п'ятій родині. А отже, дедалі актуальнішою стає проблема запобігання та протидії насильству в сім’ї, пошуку найбільш оптимальних та ефективних шляхів цієї роботи.

Аналіз останніх досліджень, у яких започатковано розв'язання цієї проблеми. Різні аспекти профілактики та подолання домашнього насильства в останні десятиріччя стали об'єктом пильної уваги багатьох зарубіжних та вітчизняних науковців і практиків. Так, зокрема, наукові засади попередження та подолання причин і наслідків насильства в сім'ї знайшли відображення у працях Т. Алєксєєнко, О. Балакірєвої, О. Безпалько, А. Бондаровської, О. Бондарчука, Т. Говорун, О. Кікінежді, М. Ліборакіної, Н. Лавриненко, А. Троцко, I. Трубавіної, Ю. Якубова та ін. Питання соціально-педагогічної роботи з профілактики домашнього насильства щодо дітей висвітлено у працях І. Алексєєва, О. Балакіревої, О. Безпалько, А. Бондаровської, О. Бондарчука, Я. Бордіян, Л. Булах, І. Трубавіної, Н. Шведової, О. Шинкаренко та ін. Науковці Ю. Антонова, Л. Берковиц, Н. Блеклок, А. Бова, Ю. Гарбер, К. Левін, Р. Максудов, М. Орел, І. Шуригіна тощо головну увагу зосереджують на проблемах профілактики та подолання насильства щодо жінок, на особливостях соціальної роботи $з$ жінками, які постраждали від насильства.

Виділення невирішених раніше частин загальної проблеми. Незважаючи на досить широке висвітлення означеної проблеми у науковій літературі, не можна стверджувати, що різні іiі аспекти в теоретичному й технологічному плані є достатньо розробленими, оскільки продовжується вивчення зарубіжного досвіду розв'язання означеної проблеми, зазнають змін умови життєдіяльності сімей, характер і специфіка надання їм різних видів соціальної допомоги та соціальних послуг, з'являються нові інституції, покликані працювати 3 жертвами домашнього насильства та їх кривдниками, удосконалюється нормативно-правова база забезпечення профілактики домашнього насильства в Україні й т.ін.
Метою даної статті $є$ висвітлення актуальних проблем, що гальмують процес запобігання й протидії домашньому насильству та перспектив цієї ланки соціальної роботи в сучасних умовах України.

Виклад основних результатів дослідження. Соціально-економічні зміни, що відбулися в Україні від початку 90-х р., значною мірою відбилися на життєдіяльності багатьох сімей, посиливши їх дезорганізацію, спричинили різке зростання кількості неблагополучних сімей, сприяли винесенню на поверхню і такої проблеми, яка здавна існувала, але довгий час замовчувалася, як домашне насильство, об'єктом якого можуть бути будь-які члени родини.

Досить тривала відсутність пильної уваги вітчизняних науковців і практиків до означеної проблеми пояснюється насамперед певною закритістю теми, ментальними особливостями сприйняття означеного феномену, намаганням членів сім'ї “не виносити 3 хати сміття”, адже більшістю населення насильство асоціювалося винятково 3 нанесенням фізичної шкоди та їі видимими ознаками. Лише віднедавна ця проблема в нашій країні почала усвідомлюватися як особливо гостра і масштабна, здатна породжувати багато інших актуальних як соціальних, так і особистісних проблем, стала предметом широкого громадського та наукового дискурсу, що сприяло формуванню нового розуміння феномену домашнього насильства - не тільки як тілесних ушкоджень жертви, які можна побачити одразу, але й як систематичного психологічного тиску, обмеження базових життєвих потреб людини, - тобто усього того, що зазвичай дається взнаки не з першого погляду, не одразу, але травмує людину не менше, ніж насильство фізичне. Почало формуватися усвідомлення й того, що для подолання цієї проблеми потрібна цілеспрямована масштабна й копітка профілактична робота, що має охоплювати широкі маси населення та бути спрямованою не тільки на дорослих, але й на дітей. Адже, як відзначає відомий в Україні науковець I. Трубавіна, насильство “передається з покоління в покоління, перетворюючи вихованих у насильстві дітей у жорстоких дорослих" $[5,58]$.

Окреслена у пропонованій статті мета вимагала від нас, з одного боку, з'ясування тих чинників, які гальмують процес протидії домашньому насильству, а з іншого - визначення можливих перспективних шляхів, які стануть бар'єром на шляху поширення цього виду порушення прав людини.

3 огляду на те, що феномен домашнього 
насильства здатен відбуватися у різних проявах, Законом України "Про запобігання та протидію домашньому насильству” [1] виділено такі його види, як фізичне, економічне, психологічне та сексуальне. Не зупиняючись на тлумаченні їх сутності, вважаємо за доцільне відзначити, що у працях українських і зарубіжних науковців представлено як спектр чинників, які детермінують прояви домашнього насильства (соціальні, економічні, соціально-педагогічні, соціально-медичні, правові, політичні й т.ін.) та його наслідки, серед яких як специфічні, що порізному відбиваються на особі потерпілого у залежності від його віку чи статевої приналежності, так і загальні, які завжди негативно впливають на фізичний, моральний чи психологічний стан жертви насильства. Залежно від виду насильства та об'єкту, на який воно спрямовано, усі ці наслідки можуть бути як наближеними (такими, що проявляються одразу), так і віддаленими, здатними проявлятися з часом (особливо стосовно дітей, які або самі були жертвами насильства з боку членів сім’і, або свідками насильницьких дій у своїх родинах).

Порушення психічного й фізичного здоров'я та розвитку людини, соціальна невлаштованість особистості насамперед через набуті безпорадність і госпіталізм, деструктивні відхилення у поведінці, відсутність навичок конструктивної взаємодії та спілкування - далеко не повний перелік віддалених наслідків домашнього насильства, що можуть проявитися навіть через багато років. I особливо це стосується дітей, адже навіть спостерігання дитиною за проявами насильства у сім'ї здатне відбитися на її соціалізації [2; 5].

Масштабність й гострота окресленої у пропонованій статті проблеми яскраво підтверджується численними соціальними токшоу, що демонструються сьогодні на українському телебаченні: “Стосується кожного” (“Інтер"), “Говорить Україна" (“Україна"), “Ти не один” (“СТБ”), “Небайдужа” (“5 канал”), де, за нашими підрахунками, понад 50 \% від усіх актуальних соціальних проблем, які розглядаються під час їх трансляції, становить саме проблема домашнього насильства щодо жінок і дітей. При цьому привертають увагу дві особливості. По-перше - це те, що ініціаторами звернення на програму зазвичай стають не жертви насильницьких дій, а небайдужі громадяни - сусіди, родичі, знайомі. Безумовно, на наше переконання, це вже хороший показник “оживлення” суспільної свідомості, розуміння населенням наслідків домашнього насильства.
По-друге - “героями” цих соціальних ток-шоу найчастіше стають особи (у тому числі молодь та діти) з числа сиріт та позбавлених у дитинстві батьківського піклування.

Чому це відбувається ми спробували з'ясувати у ході проведеного нами дослідження громадської думки стосовно різних аспектів проблеми домашнього насильства (його видів, причин та наслідків, поведінки людини у ситуації домашнього насильства, поінформованості стосовно інституцій, до яких слід звертатися у таких випадках, бачення респондентами шляхів превенції та подолання домашнього насильства тощо).

3 цією метою нами було опитано дві вікові групи респондентів - учнівська та студентська молодь віком від 15 до 20 р. з числа дітей-сиріт і позбавлених батьківського піклування, та представники вікової групи 40-65 р. (це насамперед вчителі, викладачі та обслуговуючий персонал закладів освіти, де навчається ця молодь). Вибір таких різновікових груп респондентів було зумовлено не випадково, оскільки ми намагалися з'ясувати, з одного боку, бачення означеної у статті проблеми молодим поколінням України і тими, чия соціалізація відбувалася насамперед у радянський період та на зламі старої й нової політичної системи країни, на зламі ціннісних життєвих орієнтацій. 3 іншого боку, акцент на опитуванні молоді саме з числа дітей-сиріт та позбавлених батьківського піклування зумовлювався тим, що травматичне дитинство накладає відбиток на соціальне становлення людини i, як свідчить практика, саме ця категорія осіб становить групу ризику, яка найчастіше потерпає від різних проявів насильства.

Опитування обох груп респондентів проводилося шляхом як анкетування, так і вільного інтерв’ю. При цьому ми намагалися максимально взаємоузгодити зміст питань для дорослоӥ аудиторії та молоді, щоби з'ясувати та порівняти бачення, усвідомлення ними не тільки сутності проблеми домашнього насильства, але й перспектив іії розв’ язання.

Насамперед відзначимо, що проблема домашнього насильства сприймається і молоддю, і старшим поколінням як надзвичайно актуальна, що потребує розв'язання, адже значна частина серед усіх опитаних нами зазнавали у своєму житті тих чи інших видів насильницьких дій або були їх свідками.

Аналіз відповідей на питання (спільне для обох груп респондентів), що стосувалися з'ясування їх обізнаності стосовно видів домашнього 


\section{ПРЕВЕНЦІЯ ДОМАШНЬОГО НАСИЛЬСТВА В УКРАЇНІ: ПРОБЛЕМИ ТА ПЕРСПЕКТИВИ}

насильства та причин, які його породжують, дав нам підставу дійти висновку, що, незважаючи на певну обізнаність респондентів у цій сфері, все таки існують і деякі стереотипи (особливо у старшого покоління) щодо розуміння, тлумачення та сприйняття домашнього насильства як соціального явища. Так, зокрема, якщо $75 \%$ опитаних вікової групи 15-20 років назвали всі види домашнього насильства, $19 \%$ - три види (фізичне, сексуальне, психологічне), і лише $6 \%$ тільки фізичне, то цілковито інші результати відповідей на це питання були отримані від респондентів вікової групи 40-65 років. Серед них лише 27 \% назвали всі види домашнього насильства. Але найбільш вражаючий результат полягав у тому, що 68 \% опитаних цієї вікової категорії асоціюють домашнє насильство винятково з фізичним (нанесенням кривдником тілесних ушкоджень). Відзначимо також, що, на наш погляд, більшість 3 них тільки у ході проведеного опитування дізнались чи усвідомили сутність психологічного та економічного насильства i, навіть давши позитивну відповідь стосовно обізнаності щодо цього, самі собі заперечували. Наприклад, систематичні необгрунтовані ревнощі з боку чоловіка, які часто закінчувалися погрозами і скандалами, заборону спілкуватися 3 коліжанками й т. ін. жінки пояснювали насамперед коханням чоловіка, його ревнощами або звичайною невріжноваженістю. Фінансові обмеження дружини, тотальний контроль $з$ боку чоловіка за витратами з сімейного бюджету найчастіше пояснювалися його бережливістю та тим, що він $є$ справжнім господарем або залежністю дружини від чоловіка, якщо іï заробіток $є$ невеликим. Щодо сексуального домашнього насильства, то, знову таки, старше покоління, асоціює його винятково 3 випадками розбещення батьками-опікунами своїх дітей.

Доволі показовими виявилися відповіді респондентів стосовно причин, які можуть провокувати домашнє насильство. Варто відзначити, що обидві групи 3-поміж головних назвали алкогольну чи наркотичну залежність когось із членів родини (100\%) та незадовільне матеріальне становище сім’і (77 \%). Серед інших першорядних причин, які були названі насамперед респондентами старшої вікової групи, - зради когось із подружжя (39\%), перенесення досвіду насильства з батьківських сімей у власні сім’і (79\%) та невиконання батьківських обов'язків (35\%).

Зауважимо, що модель негативної поведінки батьків, яку діти спостерігають у власних сім'ях, залишаючись в їх свідомості, потім наслідується і відтворюється в дорослому житті. Це той спусковий гачок, який здатен штовхати людину до вчинення насильства у різних його формах і проявах часто не тільки тому, що людина цього хоче, а насамперед тому, що вона просто не знає і не вміє чинити в інший спосіб. При цьому шукає і навіть знаходить виправдання своїй поведінці. Так, зокрема, фізичне покарання власної дитини розцінювалося значною частиною респондентів старшої вікової групи як дієвий метод виховання. Як аргументи під час нашого спілкування вони наводили такі приклади: доки дитина була мала, то ставили ї̈ в кут, а коли підросла, вдавалися до ляпасів, бралися за ремінь, а щзо робити, якщо німзо інше не діє? тощо.

Відзначимо також, що серед респондентів старшої вікової групи суттєвою першопричиною домашнього насильства було окреслено незадовільне матеріальне забезпечення сім'і, що, як наслідок, відбивається на стосунках у родині. Ця причина розглядалася респондентами ще й 3 іншої точки зору - чому, наприклад, жінка терпить знущання чоловіка (боїться втратити не тільки батька дітям, але й годувальника родини; їй нікуди тікати, тому вона й вимушена терпіти й т.ін.).

Отримані результати відбивають загальну картину чинників, що можуть спричиняти прояви домашнього насильства. Водночас варто окремо зупинитися на відповідях вихованців школиінтернату, в яких простежується, на наш погляд, особистісний життєвий досвід дітей. На тлі провідної причини домашнього насильства (алкочи наркозалежності когось із батьків), діти називали такі: у нас немає рідні і тікати нам нікуди, тому ми і вимушені були терпіти знущзання батька/вітчима; мене били, тому щзо я нікому не був потрібний; мама завжди боялася мене захищати, бо бабуся з вітчимом можуть вигнати нас з хати, а ще вона й сама боялася вітчима тощо. Отже, як бачимо, відповіді вихованців інтернату не тільки розкривають причини домашнього насильства загалом, але й свідчать про намагання дітей дати пояснення проявам насильства в їх власних сім'ях й т.ін.

Наступне питання було спробою з'ясування поведінкової практики респондентів у випадках домашнього насильства (“Насильство в сім”і це те “сміття”, яке краще не виносити з хати?”) та їх обізнаності стосовно організацій та закладів, до яких можуть звернутися по допомогу потерпілі. Відзначимо, що понад $90 \%$ респондентів молодшої вікової групи відзначили, що цю проблему не треба замовчувати. 


\section{ПРЕВЕНЦЯ ДОМАШНЬОГО НАСИЛЬСТВА В УКРАЇНІ: ПРОБЛЕМИ ТА ПЕРСПЕКТИВИ}

Натомість серед відповідаючих вікової групи 4065 років показник становив лише $11 \%$, адже серед багатьох представників старшого покоління довго побутувала саме така думка (3 хати сміття не виносити). Додамо до цього ще й те, що старші люди не тільки не хотіли розголосу про свої проблеми, але й розуміли, що їм нема звідки чекати допомоги, бо довгий час домашнє насильство було проблемою самої сім’ї.

Відповіді на питання “До кого у першу чергу ви будете звертатися у випадках домашнього насильства?" наведемо у порядку їх пріоритетності: родичі, поліція, церква, сусіди. Побіжно варто звернути увагу й на те, що у процесі нашого спілкування з респондентами вони наголошували на тому, що готові повідомляти про домашнє насильство переважно тільки у випадках фізичної загрози чи сексуального насильства стосовно дитини. При цьому переважна більшість опитаних зауважували, що вони не сподіваються на дієву допомогу з боку поліції.

Серед проблемних ланок, які нам вдалося виявити, був незадовільний рівень обізнаності як серед молоді, так і серед старшого покоління щодо закладів та організацій, до яких можна звернутися по допомогу у випадках домашнього насильства. Відзначимо, що відповіді на це питання були особливо вражаючими, адже майже всі відповідаючі назвали тільки відділення поліції та лише п'ятеро респондентів із загальної кількості опитаних назвали ще центри соціальних служб для сім’ї, дітей та молоді.

Ще одне питання анкети стосувалося бачення респондентами шляхів і засобів превенції та подолання насильства в сім'ї. Питання було відкритого типу, а, отже, респонденти у довільній формі могли висловити свої думки: покращчити умови життя, щеоби у всіх була робота; карати кривдників; боротися з з алкоголізмом i наркоманією; проводити масштабні просвітнищькі заходи; удосконалити законодавство; покращити роботу правоохоронних органів тощо.

Отримані у ході проведеного дослідження результати дозволили нам виокремити найсуттєвіші проблеми, що гальмують процес подолання домашнього насильства, серед яких першорядне місце посідає недостатня поінформованість населення у цій сфері, зокрема особливо стосовно новацій.

Важливим чинником, здатним стати на шляху поширення в Україні випадків домашнього насильства, на наше переконання, має бути масштабна просвітницька робота, ознайомлення населення з головними новаціями, спрямованими на попередження та подолання насильства в сім'ї, поштовхом до застосування яких стало прийняття нової редакції Закону України “Про запобігання та протидію домашньому насильству” [1], згідно 3 яким уперше в історії вітчизняного законодавства кривдника можна притягнути не до адміністративної, а до кримінальної відповідальності за вчинення насильства. Серед інших новацій - створення, починаючи з 2018 р., при ЦСССДМ мобільних бригад соціальнопсихологічної допомоги особам, які потерпіли від домашнього насильства. Завдання фахівців цих бригад полягає у виявленні фактів вчинення домашнього насильства, проведенні роз'яснювальної інформаційної роботи з потерпілими щодо послуг, які вони можуть отримати для подолання наслідків насильства та стосовно надавачів цих послуг; надання, в разі необхідності, екстреної психологічної та соціальної допомоги; скерування потерпілих у разі необхідності до установ, покликаних працювати 3 такою категорією клієнтів.

Ще однією новацією у сфері превенції та протидії домашньому насильству слід вважати створення у 2019 р. мобільних груп поліції для реагування на факти домашнього насильства. Зауважимо, що ще до недавнього часу це була одна $з$ найслабших ланок у боротьбі з домашнім насильством, оскільки працівники органів внутрішніх справ зазвичай не втручалися у так звані “домашні конфлікти” і відповідно реагували лише на тяжкі наслідки фізичного насильства.

Переймаючи передовий зарубіжний досвід у сфері протидії домашньому насильству, в Україні започатковано також створення мережі притулків для жертв домашнього насильства. Як відзначається на сайті урядового порталу щодо цієї новації, “це будуть місця безпечного тимчасового перебування та комплексної допомоги з наданням психологічних, соціальнопобутових, соціально-медичних, інформаційних, юридичних та інших послуг” [3].

Висновки. Узагальнюючи результати проведеної роботи, вважаємо за необхідне наголосити на тому, що організація масштабної просвітницької роботи з різних питань домашнього насильства - це лише один 3 дієвих шляхів, здатних розірвати порочне коло порушення прав людини, що має бути спрямований на все населення України. При цьому така робота повинна охоплювати не тільки загальні аспекти домашнього насильства, але й враховувати регіональні можливості при ознайомленні 3 установами та закладами, здатними надати допомогу потерпілим у конкретній місцевості, конкретному місті чи області. 


\section{СЦЕНІЧНА ДІЯЛЬНІСТЬ ЗОЇ ХРИСТИЧ У КОНТЕКСТІ РОЗВИТКУ ВОКАЛЬНОГО МИСТЕЦТВА УКРАЇНИ}

\section{ЛIТЕРАТУРА}

1. Закон України "Про запобігання та протидію домашньому насильству” від 7 грудня 2017 р. №2229VIII. URL: http://www.rada.gov.ua.

2. Методичний посібник для фахівців, які впроваджують корекційні програми для осіб, які вчинили насильство в сім'ї/ уклад.: Г.Ю. Мустафаєв, І.І. Довгаль. К., 2011. 192 с.

3. Постанова Кабінету Міністрів України від 22.08. 2018 p. № 655 “Про затвердження Типового положення про притулок для осіб, які постраждали від домашнього насильства та/або насильства за ознакою статі". URL: https://www.kmu.gov.ua/.../pro-zatverdzhennyatipovogo-polozhennya-pr.

4. Статистика, що шокує. URL: http://pedpresa.com.ua/ 35469-domashnje-nasylstvomovoyu-tsyfr.html.

5. Трубавіна I. М. Соціальний супровід неблагополучної сім'ї. Науково-методичні матеріали. К. ДЦССМ. 2003. 86 c.

\section{REFERENCES}

1. Zakon Ukrainu "Pro zapobigannya ta protydiju domashnjomu nasylstvu" vid 7 grudnya 2017 roku №2229VIII [The Law of Ukraine "On Prevention and
Counteraction of Domestic Violence" from 9 December 2017]. Available at: http://www.rada.gov.ua. [in Ukrainian].

2. Metodychnyi posibnyk dlja fachivtsiv, jaki vprovadzhujut korektsijni programy dlya osib, jaki vchynyly nasilstvo v simiji (2011). [Methodological manual for specialists, that implement remedial programs for persons committing domestic violence]. (Ed.). H.Y.Mustafaev, I.I.Dovhal. Kyiv, 192 p. [in Ukrainian].

3. Postanova Kabinety Ministriv Ukrainy vid 22.08.2018p. №655 "Pro zatverdzhennya Typovogo polozhennja pro prytulok dlja osib, jaki postradaly vid domashnogo nasylstva ta/abo nasylstva za oznakoju statti" [Resolution of Cabinet of Ministers of Ukraine from 22 August 2018 №655 “On Approval of Typical Position on Shelter for People Suffered from Domestic Violence and/or Violence Based on Gender"]. Available at: http://www.kmu.gov.ua/.../prozatverdzhennya-tipovogo-polozhennya-pr. [in Ukrainian].

4. Statustyka, cho shokuje [Statistics that Shocks]. Available at: http://pedprese.com.ua/35469-domashnjenasylstvomovoyu-tsyfr.html. [in Ukrainian].

5. Trubavina, I.M. (2003). Sotsialnyi suprovid neblagopolychnoji simji [Social Convoy of Dysfunctional Family]. Scientific and methodological materials. Kyiv, 86 p. [in Ukrainian].

Стаття надійшла до редакції 10.02.2021

УДК 782.071.2(477)

DOI:

Ірина Кліш, доцент кафедри народних музичних інструментів та вокалу Дрогобицького державного педагогічного університету імені Івана Франка

\section{СЦЕНІЧНА ДІЯЛЬНІСТЬ ЗОЇ ХРИСТИЧ У КОНТЕКСТІ РОЗВИТКУ ВОКАЛЬНОГО МИСТЕЦТВА УКРАЇНИ}

У статті розкривається конкурсна, концертно-виконавська і педагогічна, діяльність украӥнської співачки Зої Христич (сопрано), народної артистки Украӥни, солістки Київського театру опери та балету імені Т. Г. Шевченка. Висвітлюється широка палітра ї̈ участі у міжнародних вокальних конкурсах у Женеві (Швейчарія, 1956, диплом I ступеня), Відні (Австрія, 1959, перша премія і золота медаль), Тулузі (Франиія, 1962, срібна медаль і звання лауреата), Софії (Болгарія, 1963), всесвітньому фестивалі демократичноїмолоді i студентів у Відні (1959). Подається опис ї̈ концертних виступів і оперних спектаклів, розкривається репертуар співачки і значення ї̈ творчості у розвитку музичного мистецтва Украӥни другої половини ХХ ст.

Ключові слова: Зоя Христич; співачка; концертна практика; оперне мистецтво; вокальні конкурси; гастролі; репертуар.

Jim. 8.

Iryna Klish, Associate Professor of the Folk Musical Instruments and Vocal Singing Department Drohobych Ivan Franko State Pedagogical University

\section{CREATIVE HERITAGE OF ZOIA KHRYSTYCH ON STAGE IN THE CONTEXT OF DEVELOPMENT OF VOCAL SINGING ART OF UKRAINE}

The article reveals the competitive, concert performance, and teaching activity of Zoia Khrystych, a Ukrainian soprano singer, National Artist of Ukraine, solo singer of Kyiv Taras Shevchenko Theatre of Opera and Ballet. The author elaborates on the wide range of her activities, including participation on international vocal competitions in Geneva (Switzerland, 1956, diploma), Vienna (Austria, 1959, First Prize and Golden Medal), Toulouse (France, 1962, silver medal and awardee's title), Sofia (Bulgaria, 1963), $7^{\text {th }}$ World Festival of Youth and Students in Vienna (1959). The author provides a description of Zoia Khrystych's concert performances and opera plays; reveals the repertory of the singer and the importance of her creativity in the development of Ukrainian musical art in the second half of the $20^{\text {th }}$ century.

The cluster of renowned names of Ukrainian singers who have gained fame on prestigious stages across the 